\title{
Erratum to: Informed consent, and an ethico-legal framework for paediatric observational research and biobanking: the experience of an Italian birth cohort study
}

\author{
Virgilia Toccaceli - Laura Serino - Maria Antonietta Stazi • \\ the Piccolipiù Working Group
}

Published online: 25 April 2016

(C) Springer Science+Business Media Dordrecht 2016

Erratum to: Cell Tissue Bank (2014) 15:579-590

DOI 10.1007/s10561-014-9431-3

Unfortunately, in the original publication of the article, the Piccolipiù Working Group was inadvertently missed out in the author group.

However, it is included in this erratum.

The online version of the original article can be found under doi:10.1007/s10561-014-9431-3.

V. Toccaceli $(\varangle) \cdot$ M. A. Stazi

Genetic Epidemiology Unit, National Centre of

Epidemiology, Surveillance and Health Promotion,

Istituto Superiore di Sanità, Viale Regina Elena, 299,

00161 Rome, Italy

e-mail: virgilia.toccaceli@iss.it

L. Serino

School of Specialization in Hygiene and Preventive

Medicine, Tor Vergata University, Via Montpellier, 1,

Rome, Italy 